\title{
Tantangan Dan Peluang Penerapan Kebijakan Mandatory Sertifikasi Halal (Studi Implementasi Uu No. 33 Th. 2014 dan Pp No. 31 Th. 2019)
}

\author{
Muhamad Muhamad ${ }^{1}$ \\ ${ }^{1}$ Sekolah Tinggi Ekonomi Islam Yogyakarta, 22jan.yassar@gmail.com
}

\begin{abstract}
ABSTRAK
Penelitian bertujuan untuk mengetahui peluang dan tantangan dengan adanya penerapan kebijakan mandatory sertifikasi halal setelah pengeluaran UU No.33 Th 2014 dan PP No. 31 Th 2019. Penelitian ini dilakukan dengan menggunakan jenis penelitian mixed yaitu penelitian lapangan dan penelitian hukum, dengan pendekatan pendekatan eksploratoris. Teknik pengumpulan data yang digunakan adalah teknik: Wawancara, dokumentasi dan observasi. Data yang dikumpulkan di olah dan dianalisis dengan menggunakan analisis kualitatif dengan tahapan analisis; pemeriksaan Data (editing), penandaan data (coding), dan penyusunan data (constructing/systematizing). Hasil penelitian menunjukkan bahwa partisipasi pelaku UMKM terkait dengan pelaksanaan kebijakan mandatory sertifikasi halal masih rendah. Kemudian tantangan yang dihadapi UMKM dengan adanya kebijakan mandatori sertifikasi halal, dimulai dari: a) Kebijakan sertifikasi halal memberikan tuntutan bagi pelaku usaha agar produknya tersertifikasi halal; b) Persyaratan kelengkapan dokumen yang harus dilengkapi UMKM; c) Modal yang minim yang dimiliki dan belum beraninya berproyeksi dengan modal pinjaman menjadikan ada ketergantungan pelaku usaha khususnya mikro-kecil kepada pemerintah; d) Proses yang masih manual dan belum menggunakan aplikasi online; e) Pemenuhan kriteria halal terkait bagaimana pelaku usaha mempersiapkan bahan, produk, fasilitas produksi, prosedur tertulis untuk aktivitas kritis, dan kemampuan telusur; f) Masalah dalam internal UMKM termasuk rendahnya SDM yang dimiliki menjadikan rasa malas dan tidak antusias terhadap kebijakan yang diberlakukan (UMKM kurang tergerak mandiri) dan g) Paradigma pelaku usaha: sertifikasi halal bagi perusahaan yang beromset besar.
\end{abstract}

INFORMASI

ARTIKEL

Katakunci:

Jual beli, implementasi, sertifikasi halal, ekonomi Islam 


\section{Pendahuluan}

Perkembangan pasar muslim global sangat pesat. Ditandai dengan gaya hidup halal saat ini tidak hanya menggejala pada negara-negara yang mayoritas penduduknya muslim, tetapi juga negara berpenduduk mayoritas non muslim. Bahkan perusahaan berskala global saat ini juga telah menerapkan sistem halal. Seperti Japan Airlaines, Singapore AirLines, Qantas, America Airlines, yang menyediakan menu halal (Moslem meal). Gejala halal juga merambah negara Amerika, Australia, Jepang, Cina, India, dan negara-negara Amerika Latin. ${ }^{1}$ The State of the Global Islamic Economy Report 2018/2019 melaporkan besaran pengeluaran makanan dan gaya hidup halal umat Islam di dunia mencapai USD 2.1 triliun pada tahun 2017 dan diperkirakan akan terus tumbuh mencapai USD 3 triliun pada 2023. Langkah-langkah sedang dilakukan untuk menciptakan ekosistem 'kulu halal', yang sejalan dengan globalisasi produksi pangan mengalami dampak global. Ternyata $80 \%$ perdagangan produk halal sebagian besar dilakukan oleh negara-negara yang mayoritas penduduknya bukan muslim. ${ }^{2}$ Saat ini konsep halal terbukti memiliki nilai ekonomi yang telah diakui di dunia, baik di negara-negara yang memeluk Islam ataupun tidak.

${ }^{1}$ May Lim Charity, "Jaminan Produk Halal Di Indonesia (Halal Products Guarantee In Indonesia)", Jurnal Legilasi Indonesia, Vol. 14 N0. 01: 99 -108.2017, hlm. 100

2Aflit Nuryulia Praswati, dan Tulus Prijanto, "Measurement Moslem religion in consumer behavior", Jurnal Ekonomi E Keuangan Islam, Vol. 3 No. 2: 99-108. 2017,hlm.100
Indonesia merupakan negara dengan jumlah penduduk muslim mencapai 87,18 persen dari populasi 232,5 juta jiwa ${ }^{3}$. Ini adalah ukuran pangsa pasar produk dan jasa berbasis ekonomi syariah yang sangat besar. Sebagai negara dengan penduduk muslim terbesar di dunia, Indonesia belum dapat berperan secara optimal dalam memenuhi permintaan ini. Mengingat keadaan ekonomi Islam global, Thomshon Routers menjelaskan ${ }^{4}$ beberapa peluang potensial untuk pengembangan produk halal: makanan dan minuman halal, pariwisata Muslim, busana muslim sederhana, media dan rekreasi, farmasi dan komik, dan sistem keuangan Islam. Dalam the Global Islamic Economy Index 2018/2019, Indonesia tercatat hanya berada di posisi ke-10 sebagai produsen produk halal dunia. Tingginya permintaan akan produk halal di dunia seharusnya menjadi peluang bagi industri halal di Indonesia.

Masalah sertifikasi dan penandaan kehalalan produk dalam sistem perdagangan internasional mendapat perhatian baik dalam kerangka memberikan perlindungan terhadap konsumen Islam di seluruh dunia, sekaligus sebagai strategi tantangan persaingan globalisasi dengan berlakunya sistem pasar bebas dalam menghadapi ASEAN-AFTA, NAFTA, Masyarakat Ekonomi Eropa, dan Organisasi Perdagangan Internasional (Organisasi Perdagangan Dunia). Sistem perdagangan internasional telah lama

${ }^{3}$ Global Islamic Economy Report 2018-

${ }^{4}$ Global Islamic Economy Report 20182019 
mengakui ketentuan halal dalam CODEX yang didukung oleh organisasi internasional yang disetujui antara WHO, FAO, dan WTO. 5 Pilihan produk logo halal berarti mengonsumsi makanan dan minuman yang terjamin kesehatannya. Hal ini menjadikan produsen produk dan layanan halal meningkatkan nilai manfaat halal dari jaminan kualitas produk halal. Sehingga melalui inilah yang membuat orang percaya pada kualitas produk halal. Dengan demikian Islamic branding 6 terbukti mempengaruhi keputusan untuk membeli produk halal. ${ }^{7}$

Pemerintah Indonesia telah merespon positif pentingnya sertifikasi halal melalui beberapa regulasi. Sertifikasi dan pelabelan halal tidak hanya untuk menyelamatkan konsumen domestik yang akan menghadapi MEA, tetapi juga untuk meningkatkan daya saing produsen dan eksportir produk

${ }^{5}$ May Lim Charity, “Jaminan Produk Halal Di Indonesia (Halal Products Guarantee In Indonesia)", Junal Legilasi Indonesia, Vol. 14 N0. 01: 99 -108, 2017, hlm. 100

${ }^{6}$ Islam Brand harus menunjukkan memiliki daya tarik yang kuat pada konsumen dengan cara patuh dan taat kepada syari'at islam. Penggunaan brand tanpa harus menunjukkan kehalalan produknya karena asal produk tersebut sudah dikenal sebagai Negara Islam. Namun branding yang berasal dari Negara non muslim tetapi produknya dinikmati konsumen muslim, maka branding ini biasanya menyertakan label halal. Dikutip dari Muhammad Nasrullah, "Islamic Branding, religiusitas dan Keputusan Konsumen terhadap Produk", Jurnal Hukum Isalam (JHI), Vol.13.No.2,2015,hlm.82

${ }^{7}$ Aflit Nuryulia Praswati, dan Tulus Prijanto, "Measurement Moslem religion in consumer behavior", Jurnal Ekonomi E Keuangan Islam, Vol. 3 No. 2: 99-108. 2017,hlm.100 halal Indonesia di pasar internasional. ${ }^{8}$ Yakni dengan UU No.33 Th 2014 yang mewajibkan semua hasil produksi tersertifikasi halal. Terlebih mulai dari 17 Oktober 2019 pemerintah menurunkan peraturan turunan atau derivatif dari UU No.33 Th 2014 yakni dikeluarkan PP No. 31 Th 2019 tentang peraturan pelaksanaan UU No.33 Th 2014 tentang Jaminan Produk Halal yang memberikan penguatan peraturan sebelumnya, dan memulai penerapan yang sebenarnya dari yang awalnya voluntary menjadi mandatory. Meskipun dalam PP No. 31 Th 2019 memberikan jangka waktu selama 5 tahun sejak pemberlakuannya.

Penguatan UU No.33 th 2014 dengan PP No. 31 th 2019 pada implementasinya menimbulkan banyak polemik dikalangan stakeholder maupun pelaku industri. Dimana memiliki tantangan yang harus dihadapi dan peluang yang dapat diambil dari penerapan kebijakan mandatory sertifikasi halal ini. Salah satu kendala bagi yang akan mengajukan sertifikasi halal adalah karena standar biaya yang ditetapkan oleh LPPOM MUI yang bervariasi dari 2,8 juta rupiah hingga 3,7 juta rupiah relatif terlalu mahal untuk usaha kecil, menengah, atau yang baru dibentuk. Karena Usaha Kecil dan Usaha Menengah (UKM) berada di bawah tanggung jawab Kementerian Koperasi dan UKM, LPPOM MUI melakukannya tidak memiliki kewajiban untuk langsung mendukung UKM untuk mendapatkan sertifikat halal. Tidak hanya itu setelah pengeluaran PP

${ }^{8}$ Aflit Nuryulia Praswati, dan Tulus Prijanto, “Measurement Moslem...,hlm.103

e-ISSN: 2686-6633 
No. 31 th 2019, yang mana sertifikasi tidak lagi sepenuhnya dilakukan oleh MUI, tetapi melalui BPJPH (Badan Penyelenggaraan jaminan Produk Halal) ${ }^{9}$ merubah proses sertifikasi yang dimungkinkan jauh lebih panjang. Meskipun beberapa pihak menolak aspek "wajib" dari sertifikat halal produk yang dibawa oleh UU JPH, tetapi munculnya tren halal global telah membawa kita ke sebuah dunia di mana produk bersertifikat halal bisa memberikan keunggulan komparatif yang signifikan terutama ketika mereka bersaing. ${ }^{10}$

Kontra terbesar datang dari berbagai pihak yang merasa bahwa kehadiran UUJPH mencabut wewenang MUI dalam hal sertifikasi halal. Dimana pemerintah mengambil alih sistem yang telah dirintis oleh MUI. Di sisi lain, pro menekankan kelemahan MUI yang tak terbantahkan, MUI lemah dimata hukum karena kurangnya hukum peraturan yang menyatakan kapasitas hukum MUI sebagai satu-satunya lembaga yang berwenang menyediakan sertifikasi halal untuk produk-produk di Indonesia. Bahkan kebanyakan negara dengan penduduk muslim mayoritas, badan sertifikasi halal kurang optimal karena adanya anggapan bahwa setiap produk makanan yang diproduksi di negara tersebut adalah halal sehingga

${ }^{9} \mathrm{BPJPH}$ adalah badan yang dibentuk oleh Pemerintah untuk menyelenggarakan JPH, Penyelenggara \& JPH dilaksanakan oleh Menteri, dibentuk BPJPH yang berkedudukan di bawah dan bertanggungjawab kepada Menteri dikutip dari pasal 5 UU No.33 Th.2014

${ }^{10}$ AKIM, et.al, "The Shifting of Halal Certification System in Indonesia: From SocietyCentric to State-Centric", MIMBAR, Vol. 35 No. $1^{\text {st }}: 115-126.2019$, hlm.117 tidak diperlukan sertifikasi halal pada produk tersebut. Dalam UUJPH tidak hanya ditujukan untuk memberikan perlindungan dan jaminan kepada konsumen semata dengan pemberian sertifikasi halal. Produsen juga menuai manfaat dari UU ini yaitu dengan adanya kepastian hukum terhadap seluruh barang yang diproduksi, sehingga UUJPH akan berdampak positif bagi dunia usaha. ${ }^{11} \mathrm{Hal}$ ini membuktikan masih banyak pro dan kontra dari berbagai kalangan mengenai peraturan perundang-undangan tentang sertifikasi halal.

Sertifikasi halal menjadi salah satu instrumen yang harus diperhatikan oleh pemerintah agar Indonesia mampu bersaing di industri halal. Berdasarkan data BPS, terdapat sekitar 57 juta Usaha Mikro Kecil dan Menengah (UMKM) di Indonesia dan yang telah memiliki sertifikat halal jumlahnya masih sangat sedikit. Berdasarkan data Majelis Ulama Indonesia (MUI) selaku lembaga yang berwenang mengeluarkan sertifikasi halal, pada periode 2014-2015 telah terbit sertifikat halal nasional untuk 6.231 perusahaan dan UMKM. Meninjau UU JPH memiliki target sangat luas, dari usaha mikro, kecil dan menengah (UMKM) sampai perusahaan besar, BPJPH miliki tugas untuk memikirkan solusi untuk memperkuat dan mempersiapkan UMKM siap untuk bersaing $^{12}$ dalam menghadapi pasar global, sehingga tidak lagi dimarginalkan oleh global pasar dan

11Ma'ruf Amin, Fatwa Produk Halal Melindungi dan Menentramkan, (Jakarta: Pustaka Jurnal Halal, 2010), hlm. 79

${ }^{12}$ AKIM, et.al, "The Shifting of Halal ..., hlm.124

e-ISSN: $2686-6633$ 
produk halal asing akan tidak mendominasi pasar domestic.

Peguatan ini merubah sisi tahapan proses sertifikasi yang menuntut proses edukasi lebih pada pelaku industry juga kesiapan stakeholder. Sertifikasi tetap menjadi tantangan utama bagi industri dan harus dihadapi ${ }^{13}$. Sertifikasi halal adalah langkah operasional yang diperlukan untuk memenuhi kebutuhan muslim, tetapi tetap merupakan proses yang menantang dan kompleks. ${ }^{14}$ Dimana penerapan kebijakan mandatory sertifikasi halal ini memiliki peluang dan tantangan. Apasaja peluang dan tantangan adanya UU No.33 Th 2014 dan PP No. 31 Th 2019 perlu digali untuk mendapatkan langkah terbaik baik dari sisi pelaku industri maupun stakeholder yang terkait.

\section{Kerangka Teoretik}

\subsection{Mandatory Sertifikasi Halal}

Indonesia, dengan mayoritas berpenduduk Muslim, bahkan menjadi negara Muslim terbesar di dunia, memiliki kewajiban terhadap warga negaranya guna memberikan jaminan produk yang halal untuk dapat dikonsumsi dan/atau dipergunakan sebagai sebuah kewajiban konstitusional yang harus dilaksanakan. ${ }^{15}$ Jaminan Produk Halal, yang selanjutnya disingkat JPH adalah kepastian hukum

13Syed Ali, CEO, Riz Global Foods dalam Global Economic Report 2018-2019 ...,hlm.125

${ }^{14}$ AKIM, et.al, "The Shifting of Halal

$$
15
$$

Aal

Lukmanul Hakim," Dissecting The Contents Of Law Of Indonesia On Halal Product Assurance", Indonesia Law Review,Vol. 5 No. 1:88-103, 2015.hlm. 88 terhadap kehalalan suatu produk yang dibuktikan dengan sertifikat halal. Setiap produk masuk, beredar, dan diperdagangkan di wilayah Indonesia wajib bersertifikat halal. Produk sendiri adalah barang dan/atau jasa yang meliputi makanan, minuman, obat, kosmetik, produk kimiawi, produk biologi, produk rekayasa genetik, serta barang gunaan yang dipakai, digunaan atau dimanfaatkan oleh masyarakat. Sertifikat halal sebagai pengakuan kehalalan suatu produk yang dikeluarkan oleh Badan Penyelenggara Jaminan Produk Halal berdasarkan farwa halal tertulis yang dikeluarkan oleh Majelis Ulama Indonesia. BJPH berkedudukan di bawah dan bertanggungjawab kepada Menteri. ${ }^{16}$ Adapun wewenangnya adalah sebagai berikut:

a. merumuskan dan nenetapkan kebijakan JPH;

b. menetapkan norma, standar, prosedur, dan kriteria JPH;

c. menerbitkan dan mencabut sertifikat halal dan Label Halal pada produk;

d. melakukan registrasi sertifikat halal pada produk luar negeri;

e. melakukan sosialisasi, edukasi, dan publikasi produk halal;

f. melakukan akreditasi terhadap LPH

g. melakukan registrasi Auditor Halal

h. melakukan pengawasan terhadap $\mathrm{JPH}$;

i. melakukan pembinaan Auditor Halal;

j. melakukan kerja sama dengan lembaga dalam dan luar negeri dibidang penyelenggaraan $\mathrm{JPH}$, bekerja sama dengan kementrian

16 PP No.31. Th.2019

e-ISSN: 2686-6633 
dan/atau lembaga terkait; LPH dan MUl.

Kewajiban konstitusional diberikan dalam bentuk kepastian hukum berupa jaminan kehalalan semua produk, baik yang dipakai, digunakan, dan/atau dimanfaatkan oleh masyarakat. Disahkan dan diundangkannya Undang-undang Republik Indonesia Nomor 33 Tahun 2014 tentang Jaminan Produk Halal sebagai bukti komitmen perlindungan secara konstitusional tersebut. ${ }^{17}$ Dengan Undang-undang Jaminan Produk Halal ini, masyarakat dapat mengkonsumsi/menggunakan produk apapun dengan nyaman, dan sehat selain juga, meningkatkan nilai tambah bagi pelaku usaha dalam menjual produk halal.

Implementasi UU JPH yang termuat dalam UU No. 33 tahun 2014 mengharuskan semua produk yang masuk dan beredar di Indonesia untuk memiliki sertifikasi halal. Meski awalnya, sertifikasi halal muncul sebagai alternatif untuk melindungi konsumen dengan menggunakan ajaran Islam sebagai fondasinya, halal sekarang tidak lagi terbatas pada kewajiban agama di antara umat Islam. ${ }^{18}$ Sertifikasi halal di Indonesia saat ini, masih mengalami berbagai kendala. Tarik ulur antara pihak Majelis Ulama Indonesia (MUI) dan pemerintah (Kementerian Agama) tentang pihak yang lebih berhak untuk memberikan sertifikat halal masih terus ber

langsung. Di Malaysia, pihak yang bertanggung jawab terkait pemberian

\footnotetext{
${ }^{17}$ Aal Lukmanul Hakim,"Dissecting The Contents ...,hlm.88

${ }^{18}$ Aflit Nuryulia Praswati, dan Tulus Prijanto, “Measurement Moslem...,hlm.102
}

sertifikat halal diberikan kepada pemerintah sehingga semua hal terkait dengan sertifikasi halal terpusat di pemerintah. Selain terkait lembaga pemberi sertifikat halal, penyebab masih sedikitnya produk atau perusahaan yang memiliki sertifikat halal MUI adalah karena ketidaktahuan para pelaku usaha terutama UMKM mengenai prosedur untuk mendapatkan sertifikat halal. Terlebih lagi banyak UMKM yang belum dikelola secara serius. ${ }^{19}$ Panjangnya prosedur yang harus dilalui dan banyaknya dokumen yang harus dimiliki untuk dapat memperoleh sertifikat halal, menyebabkan para pengusaha UMKM tidak terlalu antusias dengan sertifikasi halal.

Seperti kebanyakan negara dengan penduduk muslim yang besar, badan sertifikasi halal kurang optimal karena adanya anggapan bahwa setiap produk makanan yang diproduksi di negara tersebut adalah halal sehingga sertifikasi halal tidak terlalu diperlukan. ${ }^{20}$ Mengingat semua stakeholder masingmasing harus menyadari potensi UMKM Indonesia sebagai sebuah kekuatan yang dapat memenangkan pasar muslim global. Langkah yang harus ditempuh adalah bagaimana menyiapkan undang-undang Jaminan Produk Halal ini menjadi sebuah undang-undang yang efektif dapat

\footnotetext{
${ }^{19}$ Faqiatul MW \& Anissa HP, Model Pengembangan Industri Halal Food di Indonesia, hlm.10

${ }^{20}$ Gillani, S. H., Ijaz, F., and Khan, M. M. "Role of Islamic Financial Institutions in Promotion of Pakistan Halal Food Industry". Islamic Banking and Finance Review,Vol. 3.No.1, 29-49. 2016.
}

e-ISSN: $2686-6633$ 
berlaku dan diterapkan serta diterima, baik oleh masyarakat, pelaku usaha, lembaga-lembaga terkait, begitu juga kaitannya dengan masyarakat dan pelaku usaha internasional. Bahwa hadirnya UU-JPH ini harus mendatangkan rahmatan lil alamain sesuai dengan sifat Islam bukan malah mendatangkan kekisruhan dan kesusahan dalam penerapannya. ${ }^{21}$

Meskipun beberapa pihak menolak aspek "wajib" dari produk bersertifikat halal yang dibawa oleh UUJPH tetapi kebangkitan tren halal global telah membawa kita ke dunia dimana produk bersertifikat halal dapat memberikan keunggulan komparatif yang signifikan terutama ketika mereka harus bersaing dengan produk yang tidak bersertifikat halal. Keunggulan komparatif halal sertifikasi dapat secara singkat dikelompokkan menjadi 22 :

1. Otoritas - memastikan bahwa produk dan layanan yang diberikan sesuai dengan hukum Syariah tentang halal dan menciptakan mekanisme untuk memantau kepatuhan dengan pedoman dan standar baku bahan dan proses produksi;

2. Keyakinan - memberikan jaminan kepada Muslim konsumen (dan konsumen lain yang jatuhkan preferensi mereka untuk produk halal);

3. Keunggulan kompetitif - memperluas cakupan pasar menuju kesiapan untuk bertemu kebutuhan global;

4. Kualitas - menunjukkan bahwa produk memenuhi persyaratan halal

\footnotetext{
${ }^{21}$ Aal Lukmanul Hakim," Dissecting The Contents ...,hlm.88

${ }^{22}$ AKIM, et.al, "The Shifting of Halal ...,hlm.117
}

dan standar praktik kebersihan dan ketat kesehatan; dan

5. Penerimaan internasional dan pasar ekspor simbol jaminan produk atau identitas

Dari perspektif internasional kerja sama, pergeseran halal Indonesia sistem manajemen sertifikasi dari masyarakat ke tangan pemerintah menjelaskan struktur kerja sama internasional itu mungkin terjadi. Itu terjadi karena polanya hubungan yang awalnya terjadi antara aktor dari berbagai tingkatan, seperti Non-Pemerintah ke Pemerintah, telah menjadi lebih setara.

Pemerintah ke Pemerintah. Jadi, negosiasi dan komunikasi proses bisa relatif lebih efektif. Ini terbukti dalam IMT-GT (Indonesia, Malaysia, Thailand Pertumbuhan-Segitiga) trilateral kerjasama, di mana ada yang spesifik kerjasama dalam industri halal. Sebelum $\mathrm{BPJPH}$ didirikan, Indonesia tidak bisa aktif berpartisipasi dalam kerja sama spesifik tersebut. Hal ini disebabkan terbatasnya kapasitas lembaga nonpemerintah untuk didiskusikan hal-hal spesifik yang terkait dengan tugas-tugas lainnya kementerian atau lembaga. Dalam hal ini, BPJPH menjadi wajah Indonesia dalam urusan halal untuk memainkan peran aktif dalam IMT-GT. ${ }^{23}$

\subsection{Supply Chain Management/SCM dan} Halal Supply Chain

Perkembangan pasar halal membutuhkan peningkatan efisiensi dalam pasar untuk dapat mengimbangi pertumbuhan tersebut. Salah satu pendekatan yang dapat digunakan ...,hlm.123

${ }^{23}$ AKIM, et.al, "The Shifting of Halal

e-ISSN: $2686-6633$ 
adalah manajemen rantai persediaan (Supply Chain Management/SCM). Menurut Noordin, dkk bahwa SCM dapat dimanfaatkan untuk meningkatkan produktifitas dan profitabilitas dari pasar halal. ${ }^{24}$ Menurut Manzouri, dkk bahwa koordinasi yang stratejik dan sistemik dari fungsi-fungsi bisnis dalam sebuah perusahaan merupakan kunci keberhasilan penerapan SCM dalam perusahaan. SCM yang bersifat tradisional dapat didefinisikan sebagai proses pengkonversian bahan mentah menjadi barang jadi untuk selanjutnya didistribusikan sampai dengan konsumen akhir. ${ }^{25}$

Dalam perkembangan industri yang semakin pesat, terutama perkembangan industri halal, SCM yang bersifat tradisional dirasa tidak cukup mengakomodasi kebutuhan pasar. Oleh karena itu, SCM berkembang sesuai dengan kebutuhan industri menjadi halal supply chain. Halal supply chain dapat didefinisikan sebagai integrasi proses dan aktivitas bisnis dari bahan baku sampai dengan konsumen akhir (from farm to plate). Jadi perbedaan antara SCM dan halal supply chain adalah tujuannya. Supply chain management (SCM) diterapkan di perusahaan supaya perusahaan dapat mengurangi biaya produksi. Di sisi lain halal supply chain digunakan

${ }^{24}$ Noordin, N., Noor, N. L., and Samicho, Z. "Strategic Approach to Halal Certification System: An Ecosystem Perspective". Procedia Social and Behavioral Sciences.pp. 79-95,hlm.79

${ }^{25}$ Manzouri, M., et.al, "Increasing

Production and Eliminating Waste through Lean Tools and Techniques for Halal Food

Companies". 2014 perusahaan dengan tujuan menjaga dan mempertahankan kehalalan produk. Menurut Soon, dkk bahwa kehalalan produk yang tetap terjaga (halal integrity) akan menjadi salah satu keunggulan kompetitif bagi produsen untuk dapat bersaing dengan produsen lain di industri yang sama. ${ }^{26}$

3). Pelaku Industri

Subsektor industry manufaktur berskala kecil dan menengah di Indoneis dinilai sebagai sektor terpenting untuk mengikis masalah gawat yang dihadapi Indonesia, yakni pengangguran, setengah pengangguran, mengingat teknologi yang lazim dilaukan dalam proses produksinya adalah teknologi padat karya. 27 Terdapat perbedaan antara UMI (Usaha Mikro), UK (Usaha Kecil), UM (Usaha Menengah) dalam latar belakang atau motivasi pengusaha dalam melakukan usaha. Sebagian pengusaha mikro di Indonesia, alasan utama melakukan kegiatan tersebut adalah memperoleh perbaikan penghasilan. Hal ini menunjukan pengusaha mikro berinisiatif mencari penghaslan untuk meenuhi kebutuhan hidup keluarganya sehari-hari. Disamping itu, juga memiliki latar belakang untuk meneruskan usaha keluarganya, merasa telah dbekali keahlian, sert tidak ada kesempatan lain untuk berkarir dibidang lain.

Latar belakang usaha kecil lebih beragam, walaupun latar belakang

26Soon, J. M., Chandia, M., and Regenstein, J. M. "Halal Integrity in the Food Supply Chain",British Food Journal, 119 (1), 3951.2017,hlm.39

27Thee Kian Wie, Industrialisasi di Indonesia, beberapa kajian, (PT.Pustaka LP3ES:Jakarta.Cet.2.1996),hlm.109

e-ISSN: 2686-6633 
ekonomi juga merupakan alasan yang utama, tetapi sebagian memiliki latar belakang yang lebih realistis dengan melihat prospek uaha kedepan dengan kendala modal yang terbatas. Sebagian mempunyai alasan berusaha karena adanya peluang bisnis dan pangsa yang lebih aman dan besar. Meski faktor keturunan, maupun telah ada bekal keahlian, membuka lapangan kerja baru bagi warga setempat, serta masih terdapat pula yang memiliki alasan tidak adanya kesepatan dibidang lain denganberbagai alasan, misal pendidikan yang rendah, maupun kondisi fisik yang tidak memungkinkan.Sedangkan usaha menengah sebagian besar meiliki motivasi sama dengan pengusaha kecil yakni melihat prospek usaha kedepan, adanya peluang dan pangsa pasar yang aman dan besar. Yang mana secara umum lebih berorientasi bisnis dibandingkan pengusaha usaha mikro. 28

\section{Metode Penelitian}

Penelitian ini dilakukan dengan menggunakan pendekatan penelitian mixed yaitu penelitian lapangan dan penelitian hukum. Adapun obyek penelitiannya adalah pemberlakuan atau implementasi hukum yang diteliti dalam penelitian ini yaitu terkait dengan sejauh mana implementasi PP No.31 th 2019 dan UU No.33 th 2014 tentang UU Jaminan Produk Halal yang menjadi dasar pemberlakuan sistem baru pelaksanaan sertifikasi halal dari voluntary ke mandatory. Penelitian ini

\footnotetext{
${ }^{28}$ Tulus T.H. Tambunan.Usaha Mikro, kecil dan menengah, (Ghalia Indonesia:Bogor.Cet.1.2017)H.6
}

akan mengkaji apa saja tantangan dan peluang terhadap penerapan kebijakan tersebut baik dari perspektif pelaku industry ataupun pengawal kebijakan.

Pendekatan masalah yang digunakan penulis adalah pendekatan eksploratoris. Pendekatan eksploratoris bertujuan untuk memperdalam pengetahuan mengenai suatu gejala tertentu, atau untuk mendapatkan ideide baru mengenai suatu gejala itu. Pendekatan ekploratoris, umumnya dilakukan terhadap pengetahuan yang masih baru, belum banyak informasi mengenai masalah yang diteliti, atau bahkan belum ada sama sekali. ${ }^{29}$ Penelitian kualitatif exploratoris secara umum penelitian kualitatif yang cenderung menjadi lebih terbuka untuk menggunakan berbagai macam bukti dan menemukan persoalan-persoalan baru. ${ }^{30}$

Sumber data penelitiannya dibagi menjadi dua jenis, yaitu sumber data primer dan sumber data sekunder. ${ }^{31}$ Dalam melaksanakan penelitian in, diperlukan data primer digunakan sebagai dasar untuk pengambilan tindakan data sekunder sebagai pendukung dalam penelitian.

29 Amirudin dan Zainal Asikin, Pengantar Metode Penelitian Hukum, (Jakarta: PT Raja Grafindo Persada, 2012). Hlm. 25

30 W.Lawrence Neuman.Metodologi Penelitian Sosial..., hlm.50

31Sumber data primer adalah sumber data yang langsung dapat memberikan data kepada pengumpul data. Sedangkan sumber data sekunder merupakan sumber data yang tidak langsung memberikan data kepada pengumpul data, dikutip Lexi J. Meleong, Metodologi Penelitian Kualitatif, (Bandung:PT.Remaja Rosdakarya 2008),hlm.157 e-ISSN: 2686-6633 
1. Data primer, yaitu data yang diperoleh langsung dari responden pada objek yang diteliti dan ada hubungannya dengan obyek yang diteliti. Data tersebut bisa diperoleh langsung dari lapangan.32 Dalam penelitian ini, sumber data utama diperoleh dari BPJPH-Kemenag Daerah Pati, Pelaku usaha skala kecil dan mikro daerah Pati-Kudus. Sumber data utama lain adalah LPPOM-MUI Jawa Tengah, dan Tokoh Masyarakat.

2. Data Sekunder, adalah data yang bukan diusahakan sendiri pengumpulannya oleh peneliti, misalnya dari buku, dokumendokumen perusahaan, atau organisasi, surat kabar dan majalah, ataupun publikasi lainnya. ${ }^{33}$

Teknik pengumpulan data yang digunakan adalah teknik: Wawancara, dokumentasi dan observasi. Data yang dikumpulkan di olah dan dianalisis dengan menggunakan analisis kualitatif dengan tahapan analisis sebagai berikut:34

a) Pemeriksaan Data (editing)

b) Penandaan Data (coding)

c) Penyusunan/Sistematisasi Data (constructing/systematizing)

Teknik Analisis kualitatif digunakan dengan mengacu pada norma hukum yang terdapat dalam peraturan perundang-undangan serta norma-norma yang hidup dan

\footnotetext{
32Tika, dan Moh.Pabundu, Metodologi Riset Bisnis, (Jakarta: Bumiaksara,2006), hlm.57

${ }^{33}$ Marzuki,Metodologi Riset (Panduan

Penelitian Bidang Bisnis dan Sosial ), (Yogyakarta:Ekonisia,2005), hlm.60

${ }^{34}$ Anisa Cahaya Pratiwi,Pencantuman Sertifikasi Halal ...,hlm.47
}

berkembang dalam masyarakat. ${ }^{35}$ Analisis secara kualitatif juga menguraikan data secara bermutu dalam bentuk kalimat yang teratur, runtun, logis, tidak tumpang tindih dan efektif sehingga memudahkan interpretasi data dan pemahaman hasil analisis, kemudian ditarik kesimpulan sehingga diperoleh gambaran yang jelas mengenai jawaban dari permasalahan yang dibahas. ${ }^{36}$

Data dalam penelitian ini akan diuraikan ke dalam kalimat-kalimat yang tersusun secara sistematis, sehingga diperoleh gambaran yang jelas dan pada akhirnya dapat ditarik kesimpulan secara deduktif, yang mana pendekatan deduktif memulai dengan konsep abstrak atau proporsi teoritis yang menguraikan hubungan yang logis antar konsep. Kemudian mengevaluasi konsep dan proporsi terhadap konsep konkret. Dimana dalam mengembangkan atau menegaskan suatu teori yng dimulai dengan konsep abstrak dan hubungan teoritis serta mengarah kepada bukti empiris yang lebih konkret. ${ }^{37}$

\section{Hasil Penelitian dan Pembahasan}

\subsection{Prosedur Sertifikasi Halal untuk UMKM \\ Pemberlakukan UU No.33 Th.2014} (UU Jaminan Produk Halal) yang diterjemahan pula dalam PP No.31 Th.2019 menjadi fokus konsentrasi

\footnotetext{
35Zainuddin Ali, Metode Penelitian Hukum, (Jakarta: Sinar Grafika, 2011), hlm. 105.

${ }^{36}$ Anisa Cahaya Pratiwi,Pencantuman Sertifikasi Halal ...,hlm.47

37W. Lawrence Neuman.Metodologi Penelitian Sosial..., hlm.79
}

e-ISSN: $2686-6633$ 
dalam penelitian. Melalui UU JPH, pemerintah memberlakukan kebijakan publik bahwa sertifikasi halal kini bersifat mandatori bagi setiap produk yang beredar, sebagaimana yang termuat dalam Pasal 4 UU JPH: "Produk yang masuk, beredar, dan diperdagangkan diwilayah Indonesia wajib bersertifikat halal."38 Dengan pemberlakuan ini, banyak penilaian mengenai urgensi sertifikasi halal sebagai salah satu instrumen pemerintah agar Indonesia mampu bersaing diindustri halal global selain sebagai payung hukum (umbrella act) untuk consumer protection. Dalam rangka mencapai arah kebijakan ini menuntut implementasi yang efektif dilapangannya.

Adapun prosedur dalam mengurus sertifikasi halal pada suatu produk adalah sebagai berikut ${ }^{39}$ :

a. Prosesnya pelaku usaha datang ke Kemenag Kabupaten untuk melakukan pendaftaran,

b. Pendaftaran disertai dengan buktibukti pendukung, antara lain NPWP, data tentang produk, dan apabila pelaku usaha mempunyai sertifikat penyelia halal dapat disertakan. Kemudian Kemenag tingkat kabupaten memeriksa formulir kelengkapan dari pelaku usaha,

c. Setelah berkas pendaftaran pelaku usaha lengkap, berkas selanjutnya dikirim ke Kemenag Kantor Wilayah

38UU No. 33 Th. 2014 Pasal 4

${ }^{39}$ Hasil Wawancara dengan Bapak Asrul Fathi selaku (Koordinator) dan Bapak Wiwik Haris Prasetyo selaku Satgas Kabupaten Penyelenggara Syari'ah Kantor Kemenag Kudus pada tanggal 18 Maret 2020 pukul 10.10 WIB selesai
(Kanwil) Provinsi selaku Satga tingkat Provinsi dan Koordinator Satgas,

d. Sebelumnya proses awalnya dari Kanwil harus ke BPJPH Pusat, dan kini proses dari Kanwil tidak harus ke BPJPH Pusat terlebih dahulu. Setelah Kanwil diberikan hak untuk membuat surat pengantar untuk selanjutnya dipakai pelaku usaha untuk mendaftar di LPPOM,

e. Melalui surat pengantar kemudian dilakukan proses audit dan verifikasi. Proses audit yang direkomendasi baru LPPOM selaku LPH (Lembaga Pemeriksa Halal),

f. Setelah di LPH melakukan audit atau verifikasi, dari LPPOM dikirim ke MUI untuk mendapatkan rekomendasi fatwa Halal,

Setelah dari MUI dikirim ke BPJPH untuk diterbitkan sertifikat Halal. 
Gambar 1. Alur Permohonan Sertifikat Halal

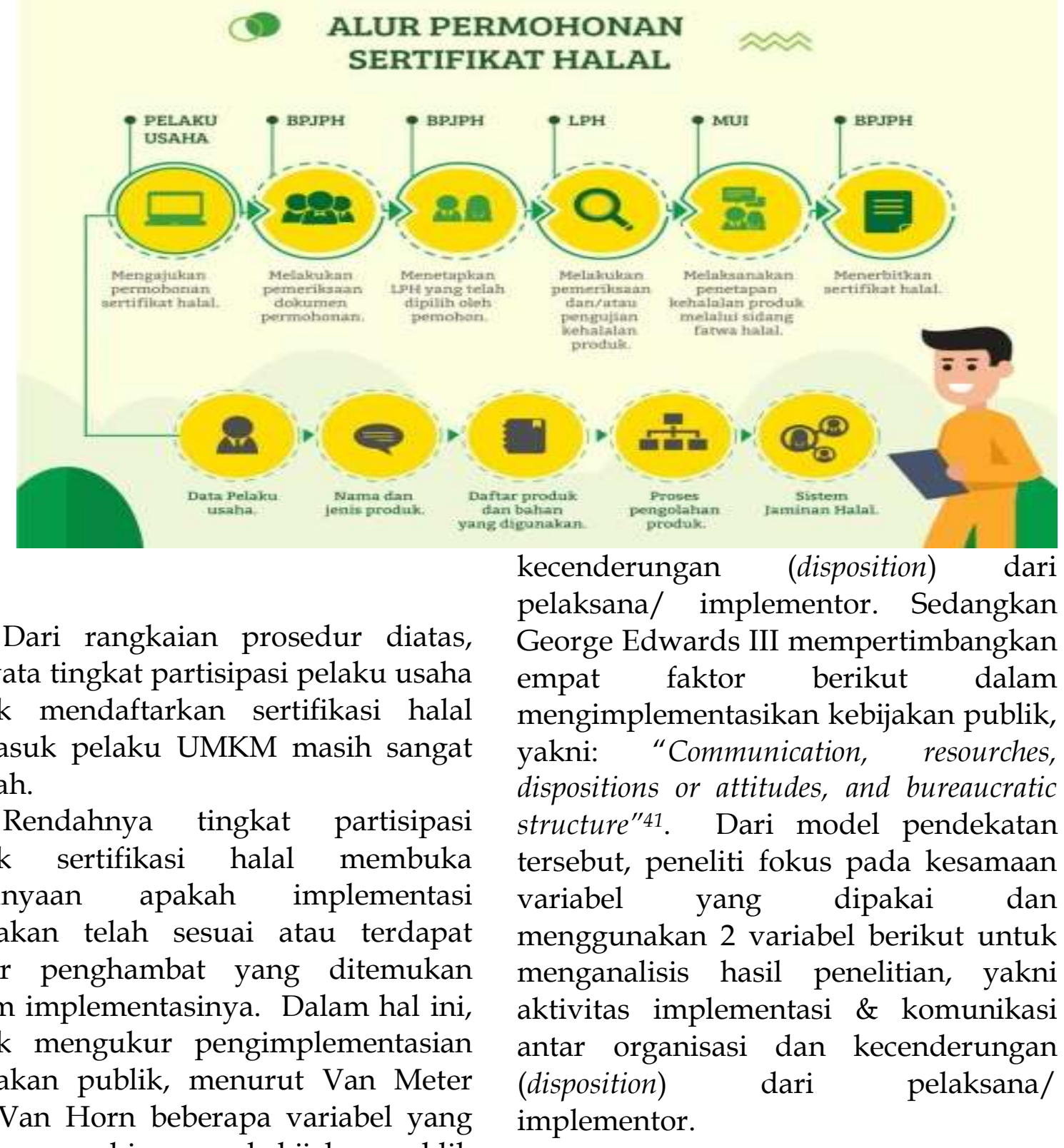
mempengaruhi proses kebijakan publik adalah;40 aktivitas implementasi \& komunikasi antar organisasi, karakteristik agen pelaksana/implementor, kondisi ekonomi, sosial \& politik, serta

\section{Tanggapan pelaku UMKM terhadap Kebijakan Mandatori Sertifikasi Halal}

Sejak UU No. 33 Th. 2014 berlaku efektif tanggal 17 Oktober 2019,

\footnotetext{
${ }^{40 Y u l i a n t o}$ Kadji , Formulasi dan implementasi Kebijakan..., hlm.54
}

41Yulianto Kadji , Formulasi dan implementasi Kebijakan..., hlm.63

e-ISSN: 2686-6633 
sertifikasi halal yang awalnya voluntary telah menjadi mandatory. Sertifikasi halal menjadi kebutuhan bagi masyarakat secara keseluruhan, terutama umat Islam untuk mendapatkan kepastian hukum atas produk-pruduk yang beredar dipasaran. Sifat mandatori dari kebijakan sertifikasi memberi tuntutan utamanya bagi produsen selaku pihak yang memproduksi produk harus mengurus sertifikasi pada produknya.

Berawal dari hal tersebut peneliti menggali tanggapan atau respon pelaku usaha terhadap kebijakan mandatori sertifikasi halal. Mengutip yang disampaikan William Dunn dalam bukunya Public Policy Analysis, an integrate approach, bahwa; "Responsiveness refers to the extent that a policy satisfies the needs, preferences, or interests of particular groups." 42 sebagai salah satu kriteria keberhasilan kebijakan, responsivitas mengacu pada sejauh mana kebijakan mampu memuaskan kebutuhan, preferensi, atau nilai-nilai kelompok masyarakat tertentu. Dengan kata lain dari sisi masyarakat, keberhasilan kebijakan dapat dilihat melalui tanggapannya tentang penerapan kebijakan baik itu tanggapan yang positif berupa dukungan ataupun wujud yang negatif berupa penolakan. Keterlibatan masyarakat penting dalam mendukung keberhasilan kebijakan, utamanya pelaku usaha yang menjadi penerima manfaat juga memiliki tuntutan untuk mentaatinya.

42Dunn, W.N., Public Policy Analysis, an integrate approach (New York: Routledge Taylor \& Francis Group. Sixth Edition. 2018), hlm.203
Dalam hal ini, peneliti mewancarai pemiliki UMKM, yang menyatakan "Sangat setuju, saya sudah pernah ikut sertifikasi. Cuma karena saya kurang kooperatif mungkin. Hanya tinggal satu langkah saja. Karena dulu saya mamang anunya (mengirimnya) di Semarang. Saya nggak (tidak) berani ke Semarang akhirnya jadi nggak (tidak) jadi. Jadi sudah pernah, tapi gagal, sudah disurvey, sedianya cukup memberikan foto saja sebetulnya." 43

Selain menyatakan tanggapan yang positif, peryataan keikutsertaan dari pelaku usaha menunjukkan adanya partisipasi masyarakat untuk mengikuti sebagaimana yang diatur UU. Namun keikutsertaan dari pelaku usaha belum dapat dijadikan tolok ukur yang pasti akan berhasilnya implementasi kebijakan. Hal ini disebabkan masih ada persyaratan, dan prosedur yang dilalui, yang dimungkinkan menjadi penghambatnya. Hal positif lain yang diungkapkan Bapak Sudarmaji, sebagai pelaku usaha ialah memberikan identifikasi tentang kendala yang dialaminya seperti tidak terpenuhinya persyaratan foto, dan kendala lokasi. Dari persetujuannya pula menunjukkan dukungan untuk berpartisipasi kembali, meskipun sebelumnya pernah mengalami kegagalan.

Kebijakan sertifikasi halal merupakan sebuah langkah yang baik. Karena pada dasarnya usaha jenang yang dikembangkannya merupakan usaha yang memproduksi produk halal

${ }^{43}$ Hasil Wawancara dengan Bapak Fathkah Sudarmaji selaku pemilik PJ Asta Jaya pada tanggal 15 Maret 2020 pukul 12.20 WIB selesai

e-ISSN: $2686-6633$ 
dengan bahan halal yang dipergunakan, baik bahan baku seperti gula, ketan, gula putih, gula aren, serta santan kelapa; juga bahan tambahan lain seperti aroma rasa. Mengutip penelitian yang dilakukan oleh Khabib S. yang menyatakan ${ }^{44}$ beberapa konsekuensi hukum syariah yang harus dipegang dalam mewujudkan keberlanjutan kehidupan dunia maupun kehidupan religi. Sebagai konsumen, manusia berkewajiban mempersiapkan dan mencari atau melakukan usaha lainnya untuk mendapatkan makanan yang halal dan baik yang nantinya akan dikonsumsi. Sedangkan bagi produsen harus memproduksi makanan yang halal dan baik sehingga tidak menimbulkan dampak negatif dan merugikan konsumen. Melalui sertifikasi halal pelaku usaha terdorong untuk memproduksi makanan halal lagi baik juga sebagai consumer protection. Sebagaimana melihat urgensi dari sertifikasi halal ${ }^{45}$ itu sendiri, memberikan kepastian hukum ketersediaan produk halal selain juga memberikan kenyamanan, keamanan dan perlindungan terhadap produk makanan, minuman, obat-obatan, kosmetika dan barang gunaan dan jasa.

${ }^{44}$ Khabib Solihin , "Analisis Kebijakan Sertifikasi Produk Halal dalam Perspektif Perlindungan Kemaslahatan Umat", Islamic Review: Jurnal Riset dan Kajian Keislaman,Vol. IX No.1 Tahun 2020,hlm.4

45Sosialisasi Jaminan Produk Halal oleh Hj. Siti Aminah, S.Ag., M.Pd.I Badan Penyelenggara Jaminan Produk Halal Kementerian Agama Republik Indonesia, yang diakses melalui https://www5.jetro.go.jp/newsletter/jkt/2019/ Pada 24 Desember 2019 pukul 11.37 WIB
Salah satu hal positif dari tanggapan pelaku usaha yakni tentang pemahaman dalam penggunaan bahan. Ibu Ngalami menambahkan, penggunaan bahan-bahan yang halal sebagai persyaratannya tidak menjadi hambatan bagi usahanya. Lebih lanjut, meskipun dalam proses sertifikasi tidak hanya menyangkut penggunaan bahan halal, tetapi terdapat pula kriteria lain seperti produk, fasilitas produksi, prosedur tertulis untuk aktivitas kritis, dan kemampuan telusur. Mengutip penelitian yang dilakukan oleh Sodiman bahwa ${ }^{46}$ kriteria diatas menjadi keharusan untuk memenuhi standart halal. 47

Tidak terlepas dari standart halal, persyaratan, maupun prosedur yang harus dilalui untuk dapat memperoleh sertifikat halal. Kebanyakan negara

46 Sodiman, "Sertifikasi Halal Produk Makanan sebagai Perlindungan Konsumen Muslim; Studi di Lembaga Pengkajian Pangan Obat-Obatan dan Kosmetika-Majelis Ulama Indonesia Sulawesi Tenggara", Li Falah Jurnal Studi Ekonomi dan Bisnis Islam.Volume 3, Nomor 1, Juni 2018.hlm. 91

47Standar halal merupakan standart yang digunakan sebagai standart produk yang memenuhi syarat kehalalan sesuai syariat Islam. Yakni tidak mengandung babi dan bahan yang berasal dari babi, tidak mengandung khomer, serta tidak mengandung bahan-bahan yang diharamkan seperti darah, kotoran, bangkai, dan bahan-bahan yang berasal dari organ manusia. Selanjutnya semua bahan yang berasal dari hewan halal yang disembelih menurut tata cara syariat Islam. Serta semua tempat penyimpanan, tempat penjualan, pengolahan dan transportasinya tidak boleh digunakan untuk babi, jika pernah digunakan untuk babi dan barang-barang tidak halal lainya harus terlebih dahulu dibersihkan dengan tata cara yang diatur dalam syariat Islam. Dikutip melalui Sodiman, "Sertifikasi Halal Produk Makanan,... hlm. 91

e-ISSN: 2686-6633 
dengan penduduk Muslim yang besar sering kali terdapat anggapan bahwa setiap produk makanan yang diproduksi di negara tersebut adalah halal sehingga sertifikasi halal tidak terlalu diperlukan. Hal tersebut dimungkinkan menjadi salah satu penyebab para pengusaha UMKM tidak terlalu antusias dengan sertifikasi halal. Meskipun demikian, pelaku usaha tidak menunjukkan penolakan kebijakan diwajibkannya sertifikasi halal. Mengingat waktu untuk merealisasikan proses sertifikasi yang diberikan 5 tahun sejak tanggal 17 Oktober 2019 sampai dengan tanggal 17 Oktober 2024 (untuk produk makanan dan minuman), dan sampai dengan tanggal 17 Oktober 2026 (untuk produk lainnya) memungkinkan bagi UMKM untuk menunda proses tersebut. Dengan demikian, waktu memadai belum tentu menjamin sertifikasi halal dapat direalisasikan tanpa adanya upaya yang massif seperti sosialisasi, edukasi urgensi sertifikasi halal, maupun fasilitas yang membantu mempermudah UMKM melalui segala prosedur, dan melengkapi persyaratan yang dipersyaratkan.

Tanggapan lain terkait kebijakan ini, Bapak Fathkah Sudarmaji menambahkan ${ }^{48}$ bahwa dari dinas-dinas setempat telah banyak disosialisasikan untuk menjadi produk halal. UMKM juga mendapat kemudahan dalam mengikuti berbagai pelatihan. Meski demikian pelaku usaha mengungkapkan, masih ada banyak hambatan yang dialami UMKM pada

${ }^{48}$ Hasil Wawancara dengan Bapak Fathkah Sudarmaji selaku pemilik PJ Asta Jaya pada tanggal 15 Maret 2020 pukul 12.20 WIB selesai umumnya, seperti: belum memenuhi persyaratan, masih ada kata malas dari UMKM sendiri selain belum banyaknya fasilitas dari dinas. Hal ini dikarenakan tanpa adanya fasilitas UMKM masih mempertimbangkan hal-hal berikut, diantaranya biaya selama proses pengurusan sertifikasi yang memberatkan pelaku usaha mengingat sebagian besar industri hanya sebagai industri rumahan dengan modal dan omset yang kecil. Belum adanya basic untuk menerapkan penggunaan modal pinjaman melalui pembiayaan bank, meski sebelumnya telah mengikuti pelatihan. Karena bagi pelaku usaha tidak semua UMKM mampu berkembang besar dan menekankan UMKM perlu difasilitasi dalam berbagai hal.

Pelaku usaha menyampaikan pula penilaiannya terhadap kebijakan sertifikasi halal, sebagai berikut; "Saya kira nanti kalau ada memfasilitasi, saya kira itu UMKM istilahnya memang home industri notabennya yang tidak berani modal banyak, istilahnya tidak berani berspekulasi. Kalau ada yang memfasilitasi yang mungkin seperti itu juga Ya pengin mengikuti. Tinggal nanti pemerintah memang proaktif mau mendatangi atau mendata, siapa saja yang nanti diikut sertakan dalam pelatihan kemudian menindak lanjuti apa yang menjadi persyaratan tersebut. Beda kalau perusahaan besar ya memang itu sarat muthlak. Saya kalau mengukur keberhasilan pemerintah itu, ya persyaratan sertifikasi halal juga tercantum, kemudian syarat-syarat menjadi produksi yang sesuai stadart nasional dan standart internasional itu berhasil tergantung pemerintahan. 
Kalau warga inikan hanya mengikuti. Kadang-kadang ada pelatihan dikasih bantuan, bantuan juga kadang-kadang tidak pas, spek nya beda misalnya, dalam bentuk mesin tapi speknya beda dengan yang diharapankan, tidak sesuai. Kadang-kadang seperti itu. Kalau pemerintah mau nanti misalnya kalau yang punya mesin dikasih mesin, itu mungkin mengena sekali. Dulu pernah dikasih .Tapi tidak standar. Contohnya mesinnya dikasih disel diatas padahal disel pakai bahan bakar, belum nanti, akhirmya tidak dipakai. Akhirnya, entahlah dulu akhirnya ditaruh disana kemudian dikanibalkan apa itu diolah. Kalau yang standar, sekarang sudah banyak yang standart. Kalau saya buatan sendiri ya kurang standart ya hanya untuk mixer saja. Kalau standar bisa dinaikkan bisa turunkan ada silinder sendiri-sendiri. Kembali ke masalah UMKM dibidang jenang ini, khususnya di warga Kaliputu yang memang sentranya, jadi pada intinya warga ini maunya juga bersaing, tapi biasanya memang terkendala dengan tempat, kalau seperti saya ini tidak bisa berkembang, ora iso tuku tanah sing luwih jembar (tidak bisa beli tanah yang lebih luas)." 49

Berdasarkan hasil wawancara diatas, terdapat point-point yang disampaikan terkait kebijakan sertikasi halal, yakni ${ }^{50}$;

${ }^{49}$ Hasil Wawancara dengan Bapak Fathkah Sudarmaji selaku pemilik PJ Asta Jaya pada tanggal 15 Maret 2020 pukul 12.20 WIB selesai

${ }^{50}$ Dapat dilihat lebih lanjut dalam lampiran (pengolahan data: transkip-kodekategorisasi)
1. UMKM berharap difasilitasi dalam segala hal

2. UMKM tidak berani modal banyak/ berspekulasi

3. Pemerintah diharapkan proaktif dan menindak lanjuti yang ditentukan

4. Sertifikasi halal bagi perusahaan besar sebagai syarat muthlak

5. Keberhasilan tergantung pemerintahan, pelaku usaha hanya menjalankan

6. Pemberian bantuan berbeda dengan yang diharapankan

7. Keterbatasan tempat membatasi pemenuhan kriteria halal

8. UMKM juga mau bersaing

Selain memberikan persetujuan sebagaimana dijelaskan sebelumnya, adanya hambatan membuat UMKM besar harapan untuk diberikan fasilitas sertifikasi halal. Pelaku usaha pula memberikan penilaian kepada kebijakan, bahwa kebijakan sertifikasi halal dengan segala persyaratan/ prosedural yang sudah tercatum untuk menjadi produksi yang sesuai stadart nasional dan standart internasional itu dapat berhasil tergantung dari pemerintahan. Pelaku usaha hanya menjalankan dan pemerintah diharapkan proaktif dan menindak lanjuti apa yang telah ditentukan. Melalui partisipasi masyarakat, dan proaktif dari pemerintah akan lebih memberikan hasil dan mendorong menuju arah kebijakan.

Keterlibatan masyarakat penting dalam mendukung keberhasilan kebijakan. Terlebih, ketika masyarakat telah memiliki pemahaman lebih baik tentang tujuan program sekaligus memberikan input. Utamanya pemahaman mengenai urgensi dari 
sertifikasi halal ${ }^{51}$ melalui stadart yang ditetapkan untuk mendorong peningkatan nilai tambah dan daya saing produk halal Indonesia di dalam \& di luar negeri; memberikan keuntungan timbal balik dalam perdagangan produk halal internasional, serta menumbuhkan kerja sama internasional dalam perdagangan produk halal.

Penyampaian adanya keterbatasan tempat membatasi pemenuhan kriteria halal, serta terkadang pemberian bantuan berbeda dengan yang diharapankan, menunjukkan masyarakat dapat mengidentifikasi kendala yang dihadapinya. Mengutip penjelasan Hayat H. bahwa ${ }^{52}$ kebijakan tidak dapat lepas dari peran serta masyarakat dalam pelaksanaanya. Masyarakat tidak hanya menjadi objek kebijakan tetapi subjek yang memiliki peran penting dalam kebijakan. Terlebih ketika paradigma sertifikasi halal yang hanya bagi perusahaan besar, dan sebagai syarat muthlak bagi perusahaan beromset besar berubah menjadi keharusan bagi seluruh pelaku usaha dengan tak terkecuali. Sebagaimana kembali pada Pasal 4 UU JPH: "Produk yang masuk, beredar, dan diperdagangkan diwilayah Indonesia wajib bersertifikat halal." ${ }^{53}$ yang

51Sosialisasi Jaminan Produk Halal oleh Hj. Siti Aminah, S.Ag., M.Pd.I Badan Penyelenggara Jaminan Produk Halal Kementerian Agama Republik Indonesia, yang diakses melalui https://www5.jetro.go.jp/newsletter/jkt/2019/ Pada 24 Desember 2019 pukul 11.37 WIB diakses

${ }^{52}$ Hayat hayat, "Buku Kebijakan Publik", https: / / www researchgate.net/publication/335 788910

53UU No. 33 Th. 2014 Pasal 4 dipahami substansinya juga urgensi dan manfaat adanya pemberlakuan kebijakan. Serta semangat UMKM dalam bersaing menjadi point penting sebagai penggerak UMKM berpartisipasi guna terwujudnya peningkatan nilai tambah dan daya saing sebagaimana yang menjadi arah kebijakan.

2. Tantangan dan peluang yang dihadapi pelaku UMKM dengan adanya penerapan kebijakan mandatori sertifikasi halal setelah pengeluaran UU No.33 Th. 2014 dan PP No. 31 Th. 2019

Pada realita dilapangan, meskipun para pihak mendorong implementasi yang efektif, implementasi kebijakan mandatori sertifikasi halal bagi UMKM di Kabupaten Kudus masih menimbulkan persoalan sebagaimana yang dibahas pada bagian awal bab. Namun, akan lebih bermakna dan membuka penyelesaian dari permasalahan yang ada, apabila persoalan-persoalan tersebut dimaknai dengan sebuah tantangan yang harus dihadapi ataupun justru sebagai sebuah peluang yang dapat dimanfaatkan pelaku usaha dalam hal ini UMKM terkait kebijakan mandatori sertifikasi halal.

Untuk itu akan dianalisa apa saja tantangan yang harus dihadapi UMKM dan apa saja peluang yang dapat dimanfaatkan UMKM dengan adanya kebijakan mandatori sertifikasi halal. Tantangan yang harus dihadapi UMKM adalah; Pertama: Kebijakan sertifikasi halal memberikan tuntutan bagi pelaku usaha agar produknya tersertifikasi halal. UU JPH yang sudah sah 
diberlakukan, artinya semua pelaku usaha, atau semua produk yang beredar harus bersertifikat halal, sebagaimana tertuang pada Pasal 4 UU No.33 Th.2014 serta Pasal 2 ayat (1) PP No.31 Th.2019. Menurut Hans Kelsen yang dikutip oleh Zumroh: "Law is coercive order of human behavior, it is the primary norm which stipulates sanction", (hukum adalah suatu perintah terhadap perilaku manusia. Hukum adalah kaedah-kaedah primer yang menetapkan sanksi-sanksi). ${ }^{54}$ Kebijakan juga memberikan sanksi administratif bagi mereka yang melanggar sebagaimana tertuang dalam Pasal 27 UU No.33 Th.2014. Sedangkan PP UU No.31 Th.2019 sebagai peraturan pejelas atau peraturan pelaksana tidak ada penterjemahan sanksi. Namun hanya diterangkan dalam pasal 2 ayat 14 PP No.31 Th.2019, sebagai berikut;

(1) Produk yang masuk, beredar, dan diperdagangkan di wilayah Indonesia wajib bersertifikat halal.

(2) Produk yang berasal dari Bahan yang diharamkan dikecualikan dari kewajiban bersertifikat halal.

(3) Produk sebagaimana dimaksud pada ayat (2) wajib diberikan keterangan tidak halal.

(4) Pelaku Usaha wajib mencantumkan keterangan tidak halal pada Produk sebagaimana dimaksud pada ayat (3).

Dalam keempat pasal tersebut, konsekuensinya setiap produk harus bersertifikasi halal, dan yang belum bersertifikat apakah menjadi tidak halal belum dijelaskan detail mengenai hal tersebut. Tidak terlepas dari itu, ketentuan ini tentu memberikan tekanan

\footnotetext{
54Zumroh Najiyah, "Implementasi Kewajiban Pendaftaran Sertifikasi..., hlm.80
}

pelaku usaha untuk mendaftarkan sertifikasi halal. Dimana apabila sampai akhir proses penahapan berakhir terdapat ketentuan pengenaan sanksi administratif bagi produk belum bersertifikat halal, yakni pelaku usaha dikenakan sanksi administratif, yang dapat berupa teguran lisan, peringatan tertulis, denda administratif, maupun dikenai publikasi melalui media resmi BPJPH. Dalam hal sanksi administratif tersebut juga tidak diindahkan, pelaku usaha wajib mencantumkan keterangan tidak halal. 55 Sebagaimana disampaikan kemenag bahwa semua produk yang beredar harus bersertifikat, baik itu halal ataupun tidak sebagai tuntutan dari undang-undang. ${ }^{56}$

Tantangan kedua, problemproblem yang harus dihadapi UMKM dalam proses serifikasi halal. Dimulai dari problem belum memenuhi persyaratan kelengkapan dokumen, yang meliputi data pelaku usaha (Izin Usaha atau kelegalan dari usaha yang dijalankan dan penyelia halal tersertifikasi); nama dan jenis produk yang tidak melanggar tau menggunakan nama-nama yang berhubugan dengan sesuatu yang haram; daftar dan bahan yang digunaka harus halal baik itu bahan baku, bahan tambahan maupun

55Sosialisasi Jaminan Produk Halal oleh Hj. Siti Aminah, S.Ag., M.Pd.I Badan Penyelenggara Jaminan Produk Halal Kementerian Agama Republik Indonesia, yang diakses melalui https://www5.jetro.go.jp/ Pada 24 Desember 2019 pukul 11.37 WIB

${ }^{56}$ Hasil Wawancara dengan Bapak Asrul Fathi selaku (Koordinator) dan Bapak Wiwik Haris Prasetyo selaku Satgas Kabupaten Penyelenggara Syari'ah Kantor Kemenag Kudus pada tanggal 18 Maret 2020 pukul 10.10 WIB selesai

e-ISSN: $2686-6633$ 
bahan penolong; proses pengolahan produk yang halal tidak melibatkan zat atau proses yang haram dilakukan; serta dokumen sistem jaminan halal.

Tantangan selanjutnya, karena modal yang minim yang dimiliki dan belum beraninya berproyeksi dengan modal pinjaman sehingga menjadikan ada ketergantungan pelaku usaha khususnya mikro-kecil pada pemerintah. Biaya selama proses sertifikasi maupun perpanjanganya cukup memberatkan bagi UKM. Perolehan margin yang tipis dan terkadang hanya memenuhi kebutuhan harian dan modal produksi berikutnya. Bahkan skala ekonomi yang terlalu kecil sulit mengharapkan untuk mampu menekan biaya mencapai titik efisieni jangka panjang. ${ }^{57}$

Proses yang masih manual dan belum menggunakan aplikasi online juga menjadi tantangan pelaku usaha. Pelaku usah harus mondar-mandir ke kantor untuk mengurus sertifikasi, terutama apabila masih terdapat kekurangan dan ketidakpahaman mengenai pesyaratan maupun alur sertifikasi halal. Bahkan diungkapkan oleh kemenag, pernah terdapat pelaku usaha yang merasakan dialih-alihkan atau istilah 'dioper-oper' ketika mengurus sertifikasi halal. Yang mana awalnya pelaku usaha melakukan registrasi di BPJPH Pusat, namun dari BPJPH Pusat diarahkan ke Kanwil, saat berada di Kanwil, pelaku usaha diarahkan ke

${ }^{57}$ Muh.Musawantoro, Peranan UMKM dalam mengembangkan Kuliner Tradisional untuk Ekonomi Masyarakat Di Sulawesi Selatan, diakses melalui https://ssrn.com/abstract=3270753 pada 26 Desember 2019 jam 08.27 WIB
Kabupaten setempat. ${ }^{58}$ Dengan demikian pelaku harus siap dan sedia dengan segala kemungkinan yang dapat terjadi akibat sistem yang masih manual.

Selanjutnya, problem mengenai pemenuhan kriteria halal masih menjadi kendala. Terkait bagaimana pelaku usaha mempersiapkan bahan, produk, fasilitas produksi, prosedur tertulis untuk aktivitas kritis, dan kemampuan telusur. Dalam bahan yang digunakan misalnya, perusahaan tidak boleh hanya menggunakan barang yang secara syariatnya halal tetapi juga harus dibuktikan dengan label yang tercantum dalam kemasan bahan, kecuali yang asli hasil dari pemasok awal seperti cabai, bawang, beras dll. Serta perusahaan menjelaskan matrik bahan disetiap produknya.

Penggunaan bahan halal juga harus disertai kebersihan fasilitas produksi yang terjaga. Seperti tersedianya tempat cuci tangan, lantai yang harus bersih atau setidaknya telah 'diplester' (dilapisi dengan semen) agar tidak menyentuh tanah langsung, adanya tempat berpisah dan tidak tercampur dengan sesuatu yang haram maupun najis. Sebagaimana disampaikan Bapak Fatkhh Sudarmaji, bahwa "mau dilabeli halal, walaupun halal tapi kotor itu tidak menjamin untuk lolos".59 Namun, keterbatasan

${ }^{58}$ Hasil Wawancara dengan Bapak Asrul Fathi selaku (Koordinator) dan Bapak Wiwik Haris Prasetyo selaku Satgas Kabupaten Penyelenggara Syari'ah Kantor Kemenag Kudus pada tanggal 18 Maret 2020 pukul 10.10 WIB selesai

${ }^{59}$ Hasil Wawancara dengan Bapak Fathkah Sudarmaji selaku pemilik PJ Asta Jaya pada tanggal 15 Maret 2020 pukul 12.20 WIB selesai

e-ISSN: 2686-6633 
tempat yang dimiliki pelaku usaha untuk menjalankan usahanya sering menghambat pelaku usaha mempersiapkannya. ${ }^{60}$ Tempat yang luas dan memadai memudahkan pelaku usaha menata dan mengatur fasilitas produksi untuk lebih terjaga kebersihaanya juga lebih menjaga dari sesuatu yang haram ataupun najis. Sebaliknya tempat yang sempit menjadikan produksi lebih sulit untuk dijaga kebersihannya, dan memungkinkan pula penggunaan wadah/fasilitas yang bersamaan pada sesuatu yang haram ataupun najis misalnya penggunaan sembarang tempat untuk peletakan bahan yang akan diolah ataupun penggunaan lorong jalan untuk penempatan olahan ${ }^{61}$. Sehingga, tantangan pelaku usaha harus menggunakan bahan yang halal dan dibuktikan dengan label halal, dan fasilitas produksi juga harus terjaga higenitas dan ke-toyyib62-annya meski keterbatasan yang dimiliki.

Dalam sertifikasi halal penggunaan sistem telusur atau Tracebility (kemampuan untuk memverifikasi lokasi asal produk ke titik penjualan)

${ }^{60}$ Hasil Wawancara dengan Bapak Fathkah Sudarmaji selaku pemilik PJ Asta Jaya pada tanggal 15 Maret 2020 pukul 12.20 WIB selesai

${ }^{61}$ Observasi pelaku usaha jenang di gang 1, Kaliputu Kecamatan Kota Kabupaten Kudus pada tanggal 15 Maret 2020

62Toyyib fokus (Toyyib focus): mencakup segala yang bergizi, aman, higienis, sehat, kesejahteraan hewan, perlakuan yang manusiawi hewan sebelum penyembelihan, menjaga kebersihan lingkungan, perdagangan yang adil dan praktik konsumsi yang berkelanjutan. Diakses melalui Mohd Imran Khan, Abid Haleem and Shahbaz Khan, “Defining Halal Supply...,hlm.6 sebagai sistem yang digunakan dan bukan "End Product Analysis". ${ }^{63}$ Dengan demikian kriteria halal dalam sertifikasi halal sesungguhnya mendorong menguatnya rantai pasokan halal. Rantai pasokan halal atau disebut halal supply chain memiliki tujuan menjaga dan mempertahankan kehalalan produk mencakup seluruh siklus hidup produk, yaitu, dari titik asal ke titik konsumsi (Farm to Fork Approach). Pada kualitas proses pelaku usaha harus berupaya menjaga kepercayaan suatu merek, kredibilitas sertifikat halal dan keluhan konsumen yang diterima mengenai status halal suatu produk. Selain itu, perusahaan wajib memiliki kemampuan mengatasi limbah fisik dalam rantai pasokan, karbon dan sumber daya yang digunakan. Bahkan menurut Tieman, rantai pasokan harus memiliki akses yang memadai ke gudang halal dan halal khusus transportasi/ kontainer bila diperlukan. ${ }^{64}$

Tantangan berikutnya adalah masalah dalam internal UMKM, yang menjadikan rasa malas dan tidak antusias terhadap kebijakan yang diberlakukan. Erat kaitannya dengan bagaimana UMKM masih menunggu adanya fasilitas atau dorongan dari pemerintah yang membuat UMKM kurang tergerak mandiri. Selain juga rendahnya SDM (Sumber Daya Manusia) yang dimiliki pelaku usaha

63Prof. Ir. Sukoso, M.Sc, Ph.D, Peraturan Terbaru Tentang Jaminan Produk Halal, hlm.18 yang diakses pada 18 Januari 2020 pukul 20.00 WIB melalui

Https:/ / Isef.Co.Id/Presentation/ISEF2019

${ }^{64}$ Marco Tieman, "Halal Supply Chain

Sertifikasi: The Next halal Supply Chain

Sertifikasi", Produced and distributed by IAIS

Malaysia.hlm.233 
khususnya dalam permodalan, pemasaran ataupun dalam inovasi produk serta managerial. Seperti kondisi saat pelaku hanya bisa menunggu konsumen datang memesan, belum adanya marketing keluar atau bahkan menjual pada grosir untuk dijualkan dengan kemasan dan merk mereka. 65 Senada dengan penelitian dari Bambang Suhardi, dkk bahwa tidak jarang unit usaha yang masih berskala mikro hanya melakukan proses produksi berdasarkan permintaan dari pelanggan (make-toorder) dan juga menyediakan produk jadi yang setiap harinya akan disebar kebeberapa outlet yang dimiliki (maketo-stock). ${ }^{66}$ Dapat ditemukan pula usaha mikro dengan alur proses yang hanya dari Supplier ke Manufacturer langsung menuju ke Customers sebagaimana PJ Asta Jaya. Sedangkan usaha kecil sudah dapat menambah alur proses dari Supplier ke Manufacturer ke Distributor/ wholesaler ke Retail outlets untuk akhirnya sampai ke Customers sebagaimana PJ Matahari.

Selain pemasaran, permodalan, inovasi, permasalahan internal dalam hal managerial juga turut menjadi tantangan pelaku usaha khususnya skala mikro-kecil. Misalnya dalam manajemen produksi, pelaku usaha memiliki tantangan bagaimana mendesain produk yang kualitas,

${ }^{65}$ Hasil Wawancara dengan Bapak Fathkah Sudarmaji selaku pemilik PJ Asta Jaya pada tanggal 15 Maret 2020 pukul 12.20 WIB selesai

66Bambang Suhardi, Serlita Vidinia Wardani, Wakhid Ahmad Jauhari, "Perbaikan Proses Produksi IKM XYZ Berdasarkan Kriteria CPPB-IRT, WISE, dan SJH LPPOM MUI", Jurnal Teknik Industri, Vol. 14, No. 2, Mei 2019.hlm.9596 meningkatkan kapasitas produksi, mengefisienkan proses produksi dan tata letak, mengoptimalkan persediaan, serta manusia dan sistem kerja yang seringkali hanya mengandalkan karyawan disekitar lingkungan mereka dan tidak dapat menjaga karyawan sebagai karyawan tetap. Selanjutnya dalam manajemen keuangan dimana pelaku usaha harus dapat memisahkan modal kerja dengan keuangan pribadi maupun melakukan pembukuan keuangan.

Sedangkan pada pelaku usaha yang telah beromset besar, yang dalam hal ini perusahaan skala besar juga menengah biasanya telah memiliki sistem managerial SDM, pemasaran, keuangan, serta produksi yang baik yang lebih terarah dan terencana. Perusahaan skala menengah memiliki motivasi melihat prospek usaha kedepan, dan adanya peluang dan pangsa pasar yang aman dan besar dan secara umum lebih berorientasi bisnis. ${ }^{67}$ Sedangkan pelaku usaha mikro cenderung lebih termotivasi untuk memperoleh perbaikan penghasilan untuk memenuhi kebutuhan hidup keluarganya sehari-hari, dan pelaku usaha skala kecil terkadang lebih realistis dengan melihat prospek usaha kedepan dengan kendala modal yang terbatas. Tidak dapat dipungkiri bahwa ada paradigma pelaku usaha mikrokecil khususnya bahwa sertifikasi halal menjadi syarat muthlak bagi perusahaan yang beromset besar. Sebagaimana disampaikan Bapak Sudarmaji; "Kalau memang omsetnya besar, ya kita

\footnotetext{
67Tulus T.H. Tambunan.Usaha Mikro, kecil dan menengah, (Ghalia Indonesia:Bogor.Cet.1.2017), hlm.6
}

e-ISSN: 2686-6633 
mungkin sangat membutuhkan"68. Karena keterbatasan yang dimiliki pelaku usaha menimbulkan rasa malas dan tidak terlalu antusias dengan kebijakan yang diberlakukan.

Dengan demikian, berikut merupakan tantangan yang dihadapi UMKM dengan adanya kebijakan mandatori sertifikasi halal, dimulai dari:

1. Kebijakan sertifikasi halal memberikan tuntutan bagi pelaku usaha agar produknya tersertifikasi halal,

2. Persyaratan kelengkapan dokumen yang harus dilengkapi UMKM,

3. Modal yang minim yang dimiliki dan belum beraninya berproyeksi dengan modal pinjaman menjadikan ada ketergantungan pelaku usaha khususnya mikro-kecil kepada pemerintah,

4. Proses yang masih manual dan belum menggunakan aplikasi online,

5. Pemenuhan kriteria halal terkait bagaimana pelaku usaha mempersiapkan bahan, produk, fasilitas produksi, prosedur tertulis untuk aktivitas kritis, dan kemampuan telusur,

6. Masalah dalam internal UMKM termasuk rendahnya SDM yang dimiliki menjadikan rasa malas dan tidak antusias terhadap kebijakan yang diberlakukan (UMKM kurang tergerak mandiri)

7. Paradigma pelaku usaha: sertifikasi halal bagi perusahaan yang beromset besar

${ }^{68}$ Hasil Wawancara dengan Bapak Fathkah Sudarmaji selaku pemilik PJ Asta Jaya pada tanggal 15 Maret 2020 pukul 12.20 WIB selesai
Sedangkan peluang yang dapat dimanfaatkan pelaku usaha khususnya UMKM dengan adanya kebijakan mandatori sertifikasi halal, adalah sebagai berikut; Pertama: sertifikasi halal memberi kenyamanan pelaku usaha dalam menjalankan usaha. Produk yang bersertifikat halal akan lebih dipilih dan dinikmati konsumen sehingga dapat meningkatkan penjualan. Hal ini dikarenakan bahwa produk halal terbukti berkualitas dan sangat baik untuk kesehatan tubuh manusia. Sebagaimana yang disampaikan Kemenag: "Logikanya kalau kita umat islam yang memperhatikan kehalalan produk pastikan memilik produk yang bersertifikat halal"69. Selain perizinan usaha ada dalam pengurusan sertifikasi, pelaku usaha juga harus mengupayakan terpenuhinya kriteria halal yang mencakup bahan, fasilitas, ketelusuran yang membuktikan kehalalan dan ketoyyibannya. Sehingga bagi pelaku usaha yang telah mengurus sertifikat halal berarti usaha yang dijalankan sudah legal, sehingga aman dan tentram dalam melaksanakan usahanya. ${ }^{70}$

Selain manfaat tersebut, peluang kedua adanya kebijakan mandatori halal adalah melalui produk yang tersertifikasi, UMKM mampu bersaing dengan produk-produk yang diproduksi perusahaan besar. Memudahkan

${ }^{69}$ Hasil Wawancara dengan Bapak Asrul Fathi selaku (Koordinator) dan Bapak Wiwik Haris Prasetyo selaku Satgas Kabupaten Penyelenggara Syari'ah Kantor Kemenag Kudus pada tanggal 18 Maret 2020 pukul 10.10 WIB selesai

70Pemaparan Bapak Asrul Fathi Penyelenggara Syari'ah Kantor Kemenag Kudus pada tanggal 18 Maret 2020 pukul 10.10 WIB selesai

e-ISSN: 2686-6633 
memasarkan ke supermarketsupermarket atau ke Distributor/ wholesaler maupun Retail outlets. Serta mendorong pelaku usaha dapat mengexpor ke pasar international. Seperti yang dilansir Suaramerdeka.com pelaku usaha yang telah mengantongi sertifikasi halal mudah tembus mall dan supermarket.71 Kebijakan sertifikasi halal memberi dorongan agar pelaku usaha memanfaatkan atmosfer yang ada untuk bersaing dan pengembangan usahanya.

Selanjutnya melalui produk yang telah tersertifikasi, terdapat potensi pasar yang besar untuk pelaku usaha apabila mampu dimanfaatkan pelaku usaha. Pasar makanan halal merupakan ${ }^{72}$ salah satu bagian industri terbesar didunia dari keseluruhan industri pangan dan pertanian global. Terlebih saat ini pengembangan sektor riil dalam hal ini adalah industri produk halal sudah menjadi perhatian tersendiri oleh pemerintah, hal ini terlihat dari upaya-upaya pemerintah dalam mengeluarkan kerangka hukum untuk pengembangan industri produk halal dalam negeri. UMKM sebagai sektor ekonomi terbesar di Indonesia dalam kuantitas mempunyai daya bangkit yang besar dalam memperkuat rantai nilai halal. Sehingga penguatan sektor UMKM akan secara langsung memperkuat industri halal dan

\footnotetext{
71Saiful Annas, "Fasilitas halal pacu daya saing UMKM", diakses melalui http://suaramerdeka.com tanggal 27 April 2020 pukul 10.12 WIB

72Riaz., Mian N. and Muhammad M. chaundry, Handbook of Halal Food Production, (Bota Raton: CRC Press Taylor \& Francis Group. 2019),hlm.67
}

mendorong pencapaian indikator atau capaian utama, baik pemerataan, kesejahteraan (welfare effect), dan juga kemandirian ekonomi bangsa. ${ }^{73}$

Peluang berikutnya, pelatihan dan fasilitas sertifikasi halal yang dilakukan sebagai bentuk penguatan sektor UMKM, menjadi pendorong pelaku usaha mengurus sertifikasi halal. Melalui edukasi masyarakat dengan berbagai pelatihan dan sosialisasi untuk menjadi produk yang halal memberi pemahaman bagi masyarakat khususnya pelaku usaha akan urgensi sertifikasi halal. Pemberian fasilitas juga memberi motivasi pelaku usaha untuk tergerak mengurus sertifikasi pada produknya. Untuk itu, keikutsertaan pelaku usaha disetiap adanya pelatihan atau fasilitas dari dinas/ pihak terkait lainnya menjadi keterbukaan pelaku usaha dalam hal pengembangan usaha, baik permodalan ataupun pemasaran, juga mempertahankan kualitas produk melalui sertifikasi halal. Terlepas dari masih minimnya fasilitas yang diberikan dan belum masifnya edukasi terkait sertifikasi halal bagi UMKM sebagaimana dijelaskan sebelumnya, keikutsertaan UMKM setiap ada pelatihan atau fasilitas menjadi peluang untuk dimanfaatkan UMKM dalam mengembangkan usaha.

Pelaku usaha yang telah menggunakan bahan halal baik dari halal perolehan seperti hasil pertanian, penyembelihan sesuai syariat islam, pengolahan hingga menghasilkan produk yang halal juga menjadi

73Bappenas, Master Plan Ekonomi Syariah Indonesia 2019-2024

e-ISSN: $2686-6633$ 
peluang untuk keikutsertaan pengurusan sertifikasi halal. Hal tersebut karena pelaku usaha telah memenuhi point penting sebagai produsen halal menyediakan produk yang halal bagi konsumen. Untuk selanjutnya pelaku usaha mempersiapkan kelengkapan lainnya untuk memenuhi persyaratan dan kriteria yang ditetapkan dan apabila dari diri pelaku usaha dirasakan bahwa tidak ada hambatan bagi pelaku usaha mengikuti sertifikasi juga turut mendorong pelaku usaha mengurus sertifikasi halal pada produknya.

Dengan demikian, berikut merupakan peluang adanya kebijakan mandatori sertifikasi halal bagi UMKM;

1. Sertifikasi halal memberi kenyamanan pelaku usaha dalam menjalankan usaha,

2. Melalui produk yang tersertifikasi, UMKM mampu bersaing dengan produk-produk yang diproduksi perusahaan besar,

3. Terdapat potensi pasar yang besar untuk pelaku usaha apabila mampu dimanfaatkan pelaku usaha,

4. Pelatihan dan fasilitas sertifikasi halal yang dilakukan sebagai bentuk penguatan sektor UMKM, menjadi pendorong pelaku usaha mengurus sertifikasi halal,

5. Pelaku usaha yang telah menggunakan bahan halal, untuk selanjutnya pelaku usaha mempersiapkan kelengkapan lainnya

\section{Kesimpulan}

Berdasarkan hasil penelitian dan analisis dapat disimpulkan sebagai bahwa tantangan yang dihadapi UMKM dengan adanya kebijakan mandatori sertifikasi halal, dimulai dari: 1) Kebijakan sertifikasi halal memberikan tuntutan bagi pelaku usaha agar produknya tersertifikasi halal; 2) Persyaratan kelengkapan dokumen yang harus dilengkapi UMKM; 3) Modal yang minim yang dimiliki dan belum beraninya berproyeksi dengan modal pinjaman menjadikan ada ketergantungan pelaku usaha khususnya mikro-kecil kepada pemerintah; 4) Proses yang masih manual dan belum menggunakan aplikasi online; 5) Pemenuhan kriteria halal terkait bagaimana pelaku usaha mempersiapkan bahan, produk, fasilitas produksi, prosedur tertulis untuk aktivitas kritis, dan kemampuan telusur; 6) Masalah dalam internal UMKM termasuk rendahnya SDM yang dimiliki menjadikan rasa malas dan tidak antusias terhadap kebijakan yang diberlakukan (UMKM kurang tergerak mandiri) dan 7) Paradigma pelaku usaha: sertifikasi halal bagi perusahaan yang beromset besar

Peluang yang dapat dimanfaatkan pelaku usaha khususnya UMKM dengan adanya kebijakan mandatori sertifikasi halal, adalah sebagai berikut: 1) sertifikasi halal memberi kenyamanan pelaku usaha dalam menjalankan usaha; 2) adanya kebijakan mandatori halal adalah melalui produk yang tersertifikasi, UMKM mampu bersaing dengan produk-produk yang diproduksi perusahaan besar; 3) Melalui produk yang telah tersertifikasi, terdapat potensi pasar yang besar untuk pelaku usaha apabila mampu dimanfaatkan pelaku usaha; 3) Sertifikasi halal memberi kenyamanan pelaku usaha dalam menjalankan usaha; 4) Melalui produk 
yang tersertifikasi, UMKM mampu bersaing dengan produk-produk yang diproduksi perusahaan besar; 5) Terdapat potensi pasar yang besar untuk pelaku usaha apabila mampu dimanfaatkan pelaku usaha; 6) Pelatihan dan fasilitas sertifikasi halal yang dilakukan sebagai bentuk penguatan sektor UMKM, menjadi pendorong pelaku usaha mengurus sertifikasi halal,

\section{Daftar Pustaka}

Aal Lukmanul Hakim," Dissecting The Contents Of Law Of Indonesia On Halal Product Assurance", Indonesia Law Review,Vol. 5 No. 1:88-103, 2015

Afiq Dwi Cahyono, "Urgensi Penerapan Sertifikasi Halal Majelis Ulama Indonesia (MUI) terhadap produk UMKM (Studi di Kota Mataram)", Jurnal Ilmiah, Mahasiswa Fakultas Hukum Universitas Mataram, 2016.

Aflit Nuryulia Praswati, dan Tulus Prijanto, "Measurement Moslem religion in consumer behavior", Jurnal Ekonomi \& Keuangan Islam, Vol. 3 No. 2: 99-108. 2017

AKIM, et.al, "The Shifting of Halal Certification System in Indonesia: From Society-Centric to StateCentric", MIMBAR, Vol. 35 No. $1^{\text {st }}: 115-126.2019$,

Amirudin dan Zainal Asikin, Pengantar Metode Penelitian Hukum, (Jakarta: PT Raja Grafindo Persada, 2012)

Anggit Listyoningrum, "Analisis Minat Beli Konsumen Muslim Terhadap Produk Yang Tidak Diperpanjang Sertifikat Halalnya", Jurnal Studi
Ekonomi dan Bisnis Islam,Vol.3. Nomor 1. 2018.

Anisa Cahaya Pratiwi,Pencantuman Sertifikasi Halal Dalam Kemasan Produk Oleh Perusahaan Sebagai Bentuk Perlindungan Hukum Terhadap Konsumen Muslim (Studi Pada Pt Japfa Comfeed Indonesia Tbk. Cabang Lampung),Skripsi Mahasiswa Fakultas Hukum Universitas Lampung Bandar Lampung, 2016

Bambang Sunggono, Metode Penelitian Hukum, (Jakarta:Raja Grafindo Persada.1997)

Burhan Ashshofa, Metode Penelitian Hukum, (Jakarta: Rineka Cipta, 2004)

Global Islamic Economy Report 20182019

Imam Salehudin dan Bagus Adi Luthfi, "Marketing Impact of Halal Labeling toward Indonesian Muslim Consumer's Behavioral Intention" ASEAN Marketing Journal . Vol.III - No. 1, June 2011

Lexi J. Meleong, Metodologi Penelitian Kualitatif, (Bandung: PT.Remaja Rosdakarya 2008)

Ma'ruf Amin, Fatwa Produk Halal Melindungi dan Menentramkan, (Jakarta: Pustaka Jurnal Halal, 2010)

Marzuki,Metodologi Riset (Panduan Penelitian Bidang Bisnis dan Sosial ), (Yogyakarta:Ekonisia,2005)

May Lim Charity, "Jaminan Produk Halal Di Indonesia (Halal Products Guarantee In Indonesia)", Junal Legilasi Indonesia, Vol. 14 N0. 01: 99 -108, 2017

PP No.31. Th.2019 
Suharsimi Arikunto, procedure Penelitian Suatu pendekatan Praktik, Edisi Revisi, (Jakarta: Rineka Cipta,2010)

Syafrida, "Sertifikat Halal Pada Produk Makanan Dan Minuman Memberi Perlindungan Dan Kepastian Hukum Hak-Hak Konsumen Muslim", ADIL: Jurnal Hukum.Vol. 7 No.2,159;174,2015

Tika, dan Moh.Pabundu, Metodologi Riset Bisnis, (Jakarta: Bumiaksara,2006)

Tulus T.H. Tambunan.Usaha Mikro, kecil dan menengah, (Ghalia Indonesia:Bogor.Cet.1.2017)

UU No.33 Th.2014

W.Lawrence Neuman.Metodologi Penelitian Sosial:Pendekatan Kualitatif dan Kuantutatif .(PT Indeks:Jakarta,2019)

Zainuddin Ali, Metode Penelitian Hukum, (Jakarta: Sinar Grafika, 2011)

Zumroh Najiyah, Implementasi Kewajiban Pendaftaran Sertifikasi Halal dalam Pasal 4 UU No.33 Th 2014 tentang Jaminan Produk Halal (Studi Pada LPPOM Jatim dan Industri Makanan dan Minuman Kota Pasuruan), Skripsi Mahasiswa Universitas Islam Negeri Maulana Malik Ibrahim Malang, 2016 